V Seminário Anual Científico e Tecnológico | Bio-Manguinhos

\title{
VAC 12 - Padronização das reações de PCR em tempo real e microarranjo líquido para determinação do título da vacina tríplice viral
}

Jéssica Malherios ${ }^{1 *}$; Gisela Freitas Trindade ${ }^{1}$; Denise Cristina de Souza Matos ${ }^{1}$; Sheila Maria Barbosa de Lima ${ }^{1}$.

1 Bio-Manguinhos / Fiocruz.

\section{Introdução:}

A prevenção contra sarampo, caxumba e rubéola no Brasil vem sendo realizada com a aplicação da vacina trivalente, composta de vírus vivos atenuados do sarampo (cepa Schwarz), da rubéola (cepa Wistar RA27/3) e da caxumba (cepa RIT 4385 derivada da cepa Jeryl-Lynn), produzidos em substratos celulares e células diploides Estudos clínicos demonstraram que esta vacina é altamente imunogênica e anticorpos contra a rubéola foram detectados em $99,3 \%$, contra o sarampo em $98,0 \%$, e contra a caxumba em $96,1 \%$ dos primovacinados. A determinação da potência da vacina é realizada por ensaios de placas de lise, que medem a quantidade de partículas infeciosas. Esses testes convencionais dependem da observação da lise celular provocada pela infecção viral. Embora este método seja considerado o padrão ouro para titulação viral, é laborioso e demanda 7 dias pós infecção para ser revelado. Atualmente, estão sendo avaliadas a utilização de técnicas modernas como qPCR e micorarranjo líquido como alternativas no controle de qualidade de vacinas.

\section{Objetivo:}

Padronizar as metodologias de microarranjo líquido e qPCR como ensaios alternativos para aferir o título dos vírus que compõem a vacina trivalente durante o processo produtivo em Bio-Manguinhos.

\section{Metodologia:}

Vacinas nas diferentes etapas de formulação (Bulk, vacina formulada e liofilizada) foram utilizadas nos ensaios. $\mathrm{O}$ ensaio de microarranjo líquido foi padronizado para avaliar o componente sarampo e para determinação da curva padrão foi utilizado anticorpo IgG (soro) específico. Neste trabalho foi feita a otimização da concentração dos oligonucleotídeos usados para cada alvo e condições de reação para qPCR, assim como a aplicação da curva padrão sintética (GBlock) para quantificação das preparações vacinais. 
A replicação dos vírus da caxumba e sarampo foi avaliada utilizando duas multiplicidades de infecção MOI 0,01 e 0,001. Foram coletadas amostras em intervalos de $24 \mathrm{~h}$, que foram quantificadas por qPCR (cópias/mL) por ensaios de placas de lise (PFU/mL).

\section{Resultado:}

A padronização realizada para o qPCR demonstrou que foi possível a quantificação dos três vírus pela técnica. Os resultados obtidos com os ensaios monoplex e biplex do qPCR quantificando as diferentes preparações vacinais foram satisfatórios, porém outras análises deverão ser realizadas para o refinamento do método. Foi iniciada a padronização do microarranjo líquido no LATIM para o vírus do sarampo que também demonstrou ser factível a utilização do ensaio, entretanto, anticorpos monoclonais específicos para cada antígeno deverão ser testados.

\section{Conclusão:}

Os dados deste estudo sugerem que a metodologia de qPCR pode ser utilizada como uma alternativa para estimar a concentração viral durante as etapas da produção e desenvolvimento da vacina, por ser um método rápido e reprodutível, o que facilita a tomada de decisões durante o processo.

Palavras-chave: Vacina trivalente; pcr em tempo real; microarranjo líquido 